\title{
Malts: Quality and phenolic content of pearl millet and sorghum varieties for brewing nonalcoholic beverages and opaque beers
}

\author{
Werner Embashu $^{1}$ (D) | Komeine K. M. Nantanga ${ }^{2}$ (ID
}

${ }^{1}$ Science and Technology Division, Multidisciplinary Research

Centre, University of Namibia, Windhoek, Namibia

${ }^{2}$ Department of Food Science and Technology, Faculty of Agriculture \& Natural Resources, University of Namibia, Windhoek, Namibia

\section{Correspondence}

Komeine K. M. Nantanga, Department of Food Science and Technology, Faculty of Agriculture \& Natural Resources, University of Namibia, Private Bag 13301, Pioneerspark, 340 Mandume Ndemufayo Ave, Windhoek, Namibia.

Email:knantanga@unam.na

\section{Funding information}

Namibian National Commission on Research, Science and Technology (NCRST), Grant/Award Number: Inc/0814/0018

\begin{abstract}
Background and objectives: The use of malted sorghum and pearl millet in the production of traditional foods and beverages is ubiquitous in Africa and India. However, there is limited industrial production and little data on the phenolic content and quality of pearl millet and sorghum malts of different varieties. Therefore, this study investigated the proximate content, malt quality, and phenolics of pearl millet (Okashana 2, Kantana, and Kangara) and sorghum (Macia and a landrace referred to as Red sorghum) varieties.

Findings: Malting increased the protein in all the varieties, except for Kangara. Germinative energies were $>97 \%$ for all varieties, except for Red sorghum. Malt quality (reducing sugars, free amino nitrogen, and $\beta$-amylase activity) was highest for Macia followed by Kantana. All pearl millet varieties and Macia had no condensed tannins. The total phenolic content and radical scavenging capacity decreased after malting for all the varieties.

Conclusions: Macia and Kantana can be candidates for industrial malting for brewing nonalcoholic beverages and opaque beers. Kantana and Red sorghum had higher amounts of phenolic compounds and can potentially be vectors of delivering phenolics into human diets.

Significance and novelty: This study investigated the phenolic content and quality of malts of different pearl millet and sorghum varieties, which can potentially be used to brew particularly low-alcohol beverages.
\end{abstract}

\section{K E Y W O R D S}

brewing, malt quality, pearl millet, phenolics, sorghum, tannins

\section{1 | INTRODUCTION}

Pearl millet (Pennisetum glaucum (L.) R.Br.) and sorghum (Sorghum bicolor (L.) Moench) are tropical cereal grains that are grown in many parts of the world such as India, the United States, Brazil, China, Australia, and Africa (Taylor, 2016a; Taylor \& Duodu, 2017). Traditionally, fermentation, malting, and milling are applied to these grains. Various traditional foods are produced which include unleavened breads, porridges, boiled grain and nonalcoholic gruels and opaque beers (Taylor, 2016b; Waniska, Rooney, $\&$ McDonough, 2016). Pearl millet and sorghum malts are made into various products including Bushera (Uganda), Fura (Nigeria), Injera (Ethiopia, Eritrea), Ting (Botswana, South Africa), Oshikundu, Omalovu (Namibia), Togwa (Tanzania), Kisra (Arabian Gulf, Sudan, Iraq), Dakuwa (Nigeria), and weaning food (India) (Adebiyi, Obadina, Adebo, \& Kayitesi, 2018; Blandino, Al-Aseeri, Pandiella, Cauntero, \& Webb, 2003; Dias-Martins, Pessanha, Pacheco, Rodrigues, \& Carvalho, 2018; Embashu, Iileka, \& Nantanga, 
2019). The malting process of sorghum for brewing of beer is relatively reported and standardized at commercial level (Owuama, 1999; Ratnavathi \& Chavan, 2016). The brewing of beer using sorghum malt exists in a number of countries such as Nigeria, Zambia, and South Africa (INTSORMIL, 2008; Kutyauripo, Parawira, Tinofa, Kudita, \& Ndengu, 2009). Furthermore, un-malted sorghum is also used as adjunct to brew a lager-type beer (Eagle lager) in Tanzania, Uganda, Zambia, and Zimbabwe (INTSORMIL, 2008). Similarly, a lager-type beer (Eagle lager) is brewed commercially using un-malted pearl millet flour (Mahangu) in Namibia. While there is limited, if any, commercial breweries that use pearl millet malts for brewing of beer, pearl millet malt is traditionally produced and used to brew alcoholic and nonalcoholic beverages at household levels in many countries in sub-Saharan Africa (Adebiyi et al., 2018; Embashu et al., 2019; Hepute, Embashu, Cheikhyoussef, \& Nantanga, 2016).

The quality of malts produced using traditional processes is generally unknown, and the traditional malting processing steps and conditions are uncontrolled and not standardized. There are relatively few studies that investigated the effects of malting conditions on the malt quality of pearl millet (Nzelibe \& Nwasike, 1995; Pelembe, Dewar, \& Taylor, 2002).

Pearl millet and sorghum grains have higher total phenolic compounds and antioxidant activities than wheat, barley, and rye (Ragaee, Abdel-Aal, \& Noaman, 2006). Phenolic compounds may confer protection against oxidative stress, cardiovascular diseases and can have anticancer properties (Awika \& Rooney, 2004; Taylor \& Duodu, 2017). Pearl millet and sorghum products are presumably some of the common vectors that deliver phenolic compounds in human diet in developing nations.

As stated, there is scant information on the malt quality of pearl millet varieties. Moreover, there is a need to understand the quality and characterize the phenolic content of malts of pearl millet and sorghum varieties for use in the production of nonalcoholic and low-alcohol opaque beverages. Therefore, this study investigated the effect of malting on the quality of malt and phenolic content of malted pearl millet and sorghum varieties for use in the production of value-added products such as beverages.

\section{MATERIALS AND METHODS}

\section{1 | Grains}

Peal millet and sorghum grains of 2015 harvest were obtained from Omahenene Agricultural Research Station $\left(17^{\circ} 26^{\prime} 30^{\prime \prime} \mathrm{S} ; 14^{\circ} 47^{\prime} 20^{\prime \prime} \mathrm{E}\right)$ of the Ministry of Agriculture, Water and Forestry in Namibia. The varieties of pearl millet grains used in this study were Okashana 2 (SDMV 93032), Kantana (landrace), and Kangara (SDMV 92040).
For sorghum, it was Macia (white, SDS 3220) and a landrace known in Oshiwambo language as Iilyawala iitiligane (which literally means "sorghum grains that are red"). The sorghum landrace is herein referred to as Red sorghum variety. The grains were grown in a sandy-loam soil under irrigation of $16 \mathrm{~mm}$ per hour every 3 days on average till fruiting stage (Megameno Amutenya, Agricultural Research Officer, Omahenene Research Station, personal communication), except when it rained. The cultivation field was fertilized with $300 \mathrm{~kg}$ per hectare of NPK (basal fertilization) during planting. At about 3 leaves stage and also before flowering, $200 \mathrm{~kg}$ per hectare of urea was applied. At the booting stage, superphosphate was also applied at $200 \mathrm{~kg}$ per hectare. The grains were obtained within one month of harvest from Omahenene Research Station where they were stored in shaded silos at ambient temperatures (apparently $20-30^{\circ} \mathrm{C}$ ). The grains were then kept at $7-10^{\circ} \mathrm{C}$ in a cooled room and were malted within one month of storage in this cooled room.

\section{2 | Malting}

Pearl millet and sorghum grains were malted according to Pelembe et al. (2002) with some modifications.

\subsection{1 | Steeping}

Grain samples $(1 \mathrm{~kg})$ were washed three times with tap water in a stainless steel bowl to remove floating materials and then steeped in static water at $20-22^{\circ} \mathrm{C}$ for $2 \mathrm{hr}$ wet and $2 \mathrm{hr}$ airrest for a total of $8 \mathrm{hr}$. Moisture content was determined at this point for malting loss determination.

\subsubsection{Germination}

After steeping, $600 \mathrm{~g}$ of the grain was transferred into shade cloth and was further wrapped in wet burlap and then incubated at $30^{\circ} \mathrm{C}$ for 4 days under saturated humidity. The bags with germinating grain were removed from the incubator and steeped in static water $\left(20-22^{\circ} \mathrm{C}\right)$ for $10 \mathrm{~min}$ and were then returned to the incubator. This was done twice daily (about $8 \mathrm{hr}$ apart) during the day.

\subsection{3 | Drying}

After the germination period (4 days), grains were removed from the bags and placed in a stainless steel tray. They were then dried in a forced draught oven at $50-55^{\circ} \mathrm{C}$ for $24 \mathrm{hr}$. The dry malt was weighed and stored at room temperature until analysis. The moisture content of dry malted grains was measured for malting loss determination. The dry malts were milled using a commercial 2-speed food blender (Waring 7011HS, USA). 


\section{3 | Determination of weight $(\mathbf{1 , 0 0 0 )}$ kernels}

The 1,000 kernel weight was determined using method described by Serna-Saldivar (2012). This was repeated five independent times $(n=6)$ per variety.

\section{4 | Determination of germinative energy}

Germinative energy, that is, the ability of the grain to germinate fully and with vigor, which is essential to normal malting was determined following method used by Ebbah, Laryea, Barimah, and Djameh (2015). This was repeated five independent times $(n=6)$ per variety.

\section{5 | Proximate analysis and malt quality}

The proximate content and reducing sugars, free amino nitrogen, and activities of amylases were analyzed in both the nongerminated grains and the malts.

\subsection{1 | Determination of proximate content}

Crude fiber (method 4.6.01) and crude fat (method 4.5.01) were determined according to AOAC (1995a,1995b) methods, crude protein was determined using combustion nitrogen analysis (CHN628 Carbon/protein/Nitrogen Analyzer) $(N \times 6.25)$, and moisture was determined using a moisture analyzer (Sartorius MA35). The proximate content was determined on both the nongerminated grains and on the malts.

\subsection{2 | Malting loss}

Shoots and roots were included in malting loss determination according to formula below:

$$
\text { Malting loss }(\%)=\frac{[[\mathrm{SGW}-(\mathrm{SGW} \times(\mathrm{SGM} / 100))]-[\mathrm{DMGW}-(\mathrm{DMGW} \times(\mathrm{DMGM} / 100))]] \times 100}{[\mathrm{SGW}-(\mathrm{SGW} \times(\mathrm{SGM} / 100))]}
$$

where SGW-steeped grains weight, SGM-steeped grains moisture (\%), DMGW-dry malt grains weight, and DMGM—dry malt grains moisture (\%).

\subsection{3 | Determination of reducing sugars}

Pearl millet and sorghum varieties reducing sugars were determined using the method by Nelson-Somogyi (1944).

\subsection{4 | Determination of free amino nitrogen (FAN)}

The FAN was determined by the European Brewery Convention Ninhydrin assay, method 8.8.1 (EBC, 1987) using glycine as a reference amino acid.

\subsection{5 | Determination of $\alpha$ - and $\beta$ - amylase activities}

The betamyl-3 and ceralpha methods by Megazyme International (2015) were used to determine the $\alpha$ - and $\beta$-amylase activities.

\section{6 | Phenolics and antioxidant activity}

\subsection{1 | Detection of tannin by bleach test}

The chlorox bleach test for qualitative determination of tannins in sorghum grain was used as described by Taylor and Taylor (2008). It was done on the nongerminated grains of sorghum and pearl millet varieties. If the grain turns black over the entire surface upon the bleach test, this indicates a positive test (presence of a pigmented testa, i.e., tannin grain). On the other hand, a completely white or brown grain over part of the surface indicates a negative test (absence of pigment testa, i.e., nontannin grain). It is noteworthy that no standard check sample was used to compare with the results observed for pearl millet and sorghum varieties sample in this study.

\subsection{2 | Extraction}

For the extraction of phenolic compounds, $0.5 \mathrm{~g}$ of nongerminated grains and malts was weighed into a 50-ml centrifuge tube. This was extracted using $5 \mathrm{ml}$ of $1 \% \mathrm{HCl}(\mathrm{v} / \mathrm{v})$ in methanol. The content was mixed and left to stand for 15 min with gentle shaking. The tubes were then placed in a sonicator (Elmasonic $\mathrm{S} 10 \mathrm{H}$ ) at $25^{\circ} \mathrm{C}$ for $10 \mathrm{~min}$ before centrifugation (Eppendorf 5810R) at $3220 \mathrm{~g}$ for $3 \mathrm{~min}$. The supernatant was decanted into a separate centrifuge tube, and the extraction was repeated once. The supernatants were stored at $-4^{\circ} \mathrm{C}$ until analysis.

\subsection{3 | Determination of total phenolic content}

Total phenolic content was determined using the Folin-Ciocalteu method as described in Ainsworth and Gillespie (2007). The estimation of phenolic content was expressed as milligrams of gallic acid equivalent per gram of sample on dry basis.

\subsubsection{Determination of flavonoid content}

The aluminum chloride method as described by Chang, Yang, Wen, and Chern (2002) was used to determine the flavonoid 
content, which was expressed as milligrams of quercetin equivalent per gram of sample on dry basis.

\subsection{5 | Determination of condensed tannins}

Condensed tannins were determined using vanillin- $\mathrm{HCl}$ method as described by Gaytán-Martínez et al. (2017). The condensed tannin content was expressed as milligrams of catechin equivalent per gram of sample on dry basis.

\subsection{6 | DPPH free radical scavenging activity}

The capacity of extracts to scavenge free radicals (2,2-diphenyl-1-picrylhydrazyl, DPPH) was determined according to the method by Gaytán-Martínez et al., (2017). The free radical scavenging ability (Sompong, Siebenhandl-Ehna, Linseberger-Martina, \& Berghofer, 2011) was calculated using the following equation:

$$
\text { Scavenging ability }(\%)=\frac{A_{\text {control }}-A_{\text {sample/AA }}}{A_{\text {control }}} \times 100
$$

where $A=$ absorbance at $515 \mathrm{~nm} ; A_{\text {control }}=$ DPPH solution without extract or standard (ascorbic acid); $A_{\text {sample }}=$ DPPH solution with extract; $A_{\mathrm{AA}}=\mathrm{DPPH}$ solution with ascorbic acid.

\subsection{7 | Statistical analysis}

The grains were malted once for each of the varieties of sorghum and pearl millet. The proximate analyses were repeated five times $(n=6)$. The malt quality and phenolic extractions were performed two independent times. The analyses were then conducted in triplicates for each of the two independent extractions. The effect of malting on malt quality and phenolics of pearl millet and sorghum varieties was determined using one-way analysis of variance (ANOVA) and Fisher's least significant difference (LSD) test at $p \leq 0.05$ using $\mathrm{R}$ software (version 3.5.2, Austria).

\section{3 | RESULTS AND DISCUSSION}

\section{1 | Kernel weight, germinative energy, and proximate content}

Kernel weight and germinative energy of nongerminated pearl millet and sorghum grains varieties are shown in Table 1. Nongerminated sorghum grain varieties had the highest $(p \leq 0.05)$ kernel weight compared to all pearl millet varieties. Among pearl millet varieties, Kangara had a relatively higher $(p \leq 0.05)$ kernel weight than the other two studied varieties. The pearl millet kernel weight of Okashana 2 and Kantana was in the range of 0.008-0.015 g/kernel reported by Abdelrahman, Hoseney, and Varriano-Marston (1984) and Serna-Saldivar and Espinosa-Ramírez (2019). However, for Kangara the kernel weight was slightly higher than the same reported range. This suggests that Kangara kernel is relatively larger and/or denser than Okashana 2 and Kantana. The kernel weight of sorghum varieties was within the reported range of 0.023-0.035 g/kernel (SernaSaldivar \& Espinosa-Ramírez, 2019; Serna-Saldival \& Rooney, 1995).

TA B L E 1 Kernel weight, crude fat, protein, fiber, and germinative energy of pearl millet and sorghum grains and malt varieties

\begin{tabular}{|c|c|c|c|c|c|}
\hline Varieties & $\begin{array}{l}\text { Kernel weight (g/ } \\
\text { kernel) }\end{array}$ & $\begin{array}{l}\text { Germinative energy } \\
(\%)\end{array}$ & Crude fat $(\%, \mathbf{d b})$ & $\begin{array}{l}\text { Crude protein } \\
(\%, \mathrm{db})\end{array}$ & $\begin{array}{l}\text { Crude fiber } \\
(\%, \mathrm{db})\end{array}$ \\
\hline \multicolumn{6}{|l|}{ Pearl millet grains } \\
\hline Kantana & $0.010 \pm 0.00 \mathrm{c}$ & $99.33 \pm 1.15 \mathrm{a}$ & $5.30 \pm 0.28 \mathrm{c}$ & $13.80 \pm 0.84 b$ & $2.05 \pm 0.07 \mathrm{f}$ \\
\hline Kangara & $0.016 \pm 0.00 \mathrm{~b}$ & $99.66 \pm 0.57 \mathrm{a}$ & $8.10 \pm 0.40 \mathrm{a}$ & $11.25 \pm 0.77 \mathrm{c}$ & $3.45 \pm 0.07 \mathrm{c}$ \\
\hline Macia & $0.030 \pm 0.00 \mathrm{a}$ & $97.66 \pm 2.08 \mathrm{a}$ & $2.40 \pm 0.14 \mathrm{fg}$ & $11.95 \pm 0.63 \mathrm{c}$ & $3.05 \pm 0.07 \mathrm{~d}$ \\
\hline Red sorghum & $0.030 \pm 0.00 \mathrm{a}$ & $93.00 \pm 4.35 \mathrm{~b}$ & $3.60 \pm 0.28 \mathrm{e}$ & $8.10 \pm 0.56$ ef & $3.80 \pm 0.28 b c$ \\
\hline \multicolumn{6}{|l|}{ Pearl millet malt } \\
\hline Okashana 2 & N/A & N/A & $4.55 \pm 0.21 \mathrm{~d}$ & $9.15 \pm 0.07 \mathrm{de}$ & $4.70 \pm 0.14 \mathrm{a}$ \\
\hline Macia (white) & N/A & N/A & $2.05 \pm 0.42 \mathrm{~g}$ & $14.75 \pm 0.07 \mathrm{~b}$ & $4.05 \pm 0.21 \mathrm{~b}$ \\
\hline Red sorghum & N/A & N/A & $2.65 \pm 0.07 \mathrm{f}$ & $9.75 \pm 0.07 \mathrm{~d}$ & $3.70 \pm 0.14 b c$ \\
\hline
\end{tabular}

Note: Values are means \pm standard deviation; values with the same letter in a column are not significantly different $(p>0.05)$. db, dry basis; N/A, not applicable; $n=6$. 
The germinative energy was statistically the same $(p>0.05)$ among the varieties of pearl millet and Macia grains, except that of Red sorghum which was significantly lower ( $p \leq 0.05$ ), but they were all higher than the recommended minimum germinative energy of $90 \%$ for sorghum by the European Brewery Convention (EBC, 1998). The germinative energy ( $>97 \%$ ) for pearl millet and Macia observed in this study is the same as that reported by Pelembe et al., (2002) for pearl millet. Red sorghum germinative energy was in the range of 94\%-95\% reported by Morrall, Boyd, Taylor, and Walt (1986) and Ebbah et al. (2015) for sorghum. However, other studies have found higher (96\%-99\%) germinative energy (Bekele, Bultosa, \& Belete, 2012) for Red sorghum.

Crude fat in nongerminated grains differed significantly $(p \leq 0.05)$ between the varieties irrespective of the cereal (Table 1). Crude fat content in nongerminated grains was in this order Kangara $>$ Okashana $2>$ Kantana $>$ Red sorghum $>$ Macia. Pearl millet varieties had significantly $(p \leq 0.05)$ higher crude fat content than sorghum varieties. Pearl millet (Okashana 2, Kantana) and sorghum (Macia, Red sorghum) varieties had fat contents that are within the respective ranges reported by Serna-Saldivar and Espinosa-Ramírez (2019). However, the crude fat content of Kangara was higher than the fat content range reported by Serna-Saldivar and Espinosa-Ramírez (2019). Malting decreased crude fat content in all the cereals except Macia. The decrease was more pronounced in pearl millet than in sorghum. Kangara had the most decrease in fat content. Adebiyi, Obadina, Adebo, and Kayitesi (2017) also observed a decrease in fat content of pearl millet following malting.
Crude protein contents of nongerminated grains of Kantana and Macia were statistically the same $(p>0.05)$ but higher than those of the other grains, whereas Okashana 2 and Red sorghum had the lowest crude protein contents. These findings were within the reported range of $6.9 \%$ 20.9\% db (Serna-Saldivar \& Espinosa-Ramírez, 2019; Taylor, 2017) for pearl millet and of 7.3\%-15.6\% db (Awika, 2017; Serna-Saldivar \& Espinosa-Ramírez, 2019) for sorghum. Unlike the fat content, the protein content increased after malting in the following order Kantana $>$ Macia $>$ Red sorghum > Okashana 2. Malting, however, did not affect the protein content of Kangara. Adebiyi et al. (2017) also noted an increase in pearl millet protein content following malting.

Crude fiber content of nongerminated grains differed significantly ( $p \leq 0.05$ ), except those of Kangara and Red sorghum. The highest crude fiber content was observed in Red sorghum and Kangara nongerminated grains. Nongerminated Kantana grains had the lowest fiber content. These results were within the range of $1.7 \%-7.3 \% \mathrm{db}$ for pearl millet and of $1.2 \%-6.6 \% \mathrm{db}$ for sorghum reported by Serna-Saldivar and Espinosa-Ramírez (2019). Malting resulted in increased fiber contents of Okashana 2, Kantana, and Macia, whereas those of Kangara and Red sorghum remained statistically ( $p>0.05$ ) unchanged. Adebiyi et al. (2017) also observed an increase in crude fiber content in pearl millet after malting.

\section{2 | Malting loss, reducing sugars, free amino nitrogen, and amylases activities}

The malting loss, reducing sugars, free amino nitrogen (FAN), and amylases activities results are given in Table 2.

TA B L E 2 Malting loss, reducing sugars, free amino nitrogen, and amylase activities of pearl millet and sorghum varieties

\begin{tabular}{|c|c|c|c|c|c|}
\hline Varieties & Malting loss (\%) & $\begin{array}{l}\text { Reducing sugars (mg/g } \\
\text { of sample, } \mathbf{d b})\end{array}$ & $\begin{array}{l}\text { FAN }(\mathrm{mg} / 100 \mathrm{~g} \text { of } \\
\text { sample, } \mathrm{db})\end{array}$ & $\begin{array}{l}\alpha \text {-amylase (PMSDU/g } \\
\text { of sample, } \mathrm{db} \text { ) }\end{array}$ & $\begin{array}{l}\beta \text {-amylase (PMSDU/g } \\
\text { of sample, } \mathrm{db})\end{array}$ \\
\hline \multicolumn{6}{|l|}{ Pearl millet grains } \\
\hline Kantana & $30.4 \pm 0.4 \mathrm{a}$ & ND & $12.6 \pm 2.3 \mathrm{~h}$ & ND & ND \\
\hline Kangara & $24.3 \pm 1.7 \mathrm{a}$ & ND & $22.2 \pm 1.1 \mathrm{~g}$ & ND & ND \\
\hline \multicolumn{6}{|l|}{ Sorghum grains } \\
\hline Macia (white) & $28.6 \pm 6.3 \mathrm{a}$ & $29.6 \pm 2.7 \mathrm{e}$ & $17.8 \pm 2.2 \mathrm{gh}$ & ND & ND \\
\hline Red Sorghum & $11.0 \pm 0.7 \mathrm{~b}$ & $30.5 \pm 2.6 \mathrm{e}$ & $31.9 \pm 1.2 \mathrm{f}$ & ND & ND \\
\hline \multicolumn{6}{|l|}{ Pearl millet malt } \\
\hline Okashana 2 & N/A & $225.9 \pm 8.8 \mathrm{~d}$ & $120.5 \pm 4.3 \mathrm{~d}$ & $24.6 \pm 1.4 \mathrm{c}$ & $2.4 \pm 0.4 b$ \\
\hline Macia (white) & N/A & $649.0 \pm 34.6 \mathrm{a}$ & $167.2 \pm 1.9 b$ & $200.6 \pm 17.1 \mathrm{a}$ & $8.3 \pm 0.2 \mathrm{a}$ \\
\hline Red Sorghum & N/A & $285.6 \pm 11.2 \mathrm{~b}$ & $111.8 \pm 9.2 \mathrm{e}$ & $55.3 \pm 1.9 \mathrm{~b}$ & $0.4 \pm 0.1 \mathrm{~d}$ \\
\hline
\end{tabular}

Note: PMSDU = pearl millet or sorghum diastatic unit; values are mean \pm standard deviation; values with the same letter in a column are not significantly different ( $p>0.05)$; ND, not detected; db, dry basis; N/A, not applicable; $n=6$. 
There was no statistically significant difference $(p>0.05)$ in the malting loss between the varieties except for Red sorghum, which had the lowest. Nevertheless, Kantana had a relatively high malting loss of $30 \%$ although it was not statistically significant from the other varieties, except for the Red sorghum. These pearl millet malting losses were higher than those $(<10 \%)$ reported by Pelembe et al. (2002) but were lower than 35\% reported by Badau, Nkama, and Jideani (2006). For sorghum, the malting losses were less than or similar to those reported by Badau et al. (2006) and Iwuoha and Aina (1997).

Reducing sugars were not detected in all the nongerminated pearl millet grains. The sorghum nongerminated varieties had small amounts of reducing sugars, which were statistically the same $(p>0.05)$. These findings are indirectly corroborated by the absence of diastatic power reported in pearl millet (Pelembe et al., 2002) and sorghum (Novellie, 1962; Novellie $\&$ De Schaepdrijver, 1986). Following malting, reducing sugars were detected in all the sorghum and pearl millet grains. Macia had the highest reducing sugars content followed by Red sorghum, then by Kantana, Okashana 2, and Kangara. The relative order of amounts of reducing sugars in all pearl millet and sorghum malts was positively linked to the respective levels of $\beta$-amylase activity (Table 2), except for Red sorghum. This is because it is $\beta$-amylase rather than $\alpha$-amylase which primarily produces fermentable sugars such as maltose (Briggs, 1998; Taylor, 2016a). The $\alpha$-amylase activity was however much higher than that of $\beta$-amylase in malts (Table 2). No amylolytic activity was detected in nongerminated grains irrespective of the cereal (Table 2). This is similar to the findings whereby no $\alpha$-amylase activity (Pelembe et al., 2002) and only negligible or no $\beta$-amylase activity (Pelembe et al., 2002; Taylor \& Robbins, 1993) were noted in nongerminated pearl millet and sorghum grains. For malts, the significant $(p \leq 0.05)$ order was Macia $>$ Kantana $=$ Red sorghum $>$ Kangara $=$ Okashana 2 . The $\alpha$-amylase activities in all the malts were higher than 17-27 PMDU/g dry weight malt reported by Pelembe et al. (2002), except for Okashana 2 , which was within the range.

The FAN was detected in both the nongerminated grains and the malts for all the cereals (Table 2). Malting resulted in a significantly increased FAN content. Malted Kantana had significantly $(p \leq 0.05)$ higher FAN contents than all the other malts. The FAN content of Macia and Kantana malts was higher, and those of Okashana 2, Kangara, and Red sorghum were lower than the FAN of $163 \mathrm{mg} / 100 \mathrm{~g} \mathrm{db}$ reported by Pelembe et al. (2002) for pearl millet malted under similar conditions.

\subsection{Phenolics and antioxidant activity}

\subsection{1 | Tannins by bleach test}

The bleach test was negative for all the pearl millet varieties (Kantana, Kangara, Okashana 2) and for Macia (Figure 1). This suggests that these grains do not have pigmented testa; thus, they do not contain tannins. According to Taylor and Taylor (2008), tannin-containing sorghum grains turn black over the entire surface when subjected to the bleach test, thereby indicating a positive test (presences of pigmented testa) tannin grains. However, the Red sorghum grains after the bleach test in this study turned partially black on the surface (Figure 1). This suggests the possibility of a presence of a pigmented testa. These results were corroborated by the quantitative data of condensed tannins reported in Section 3.3.2.
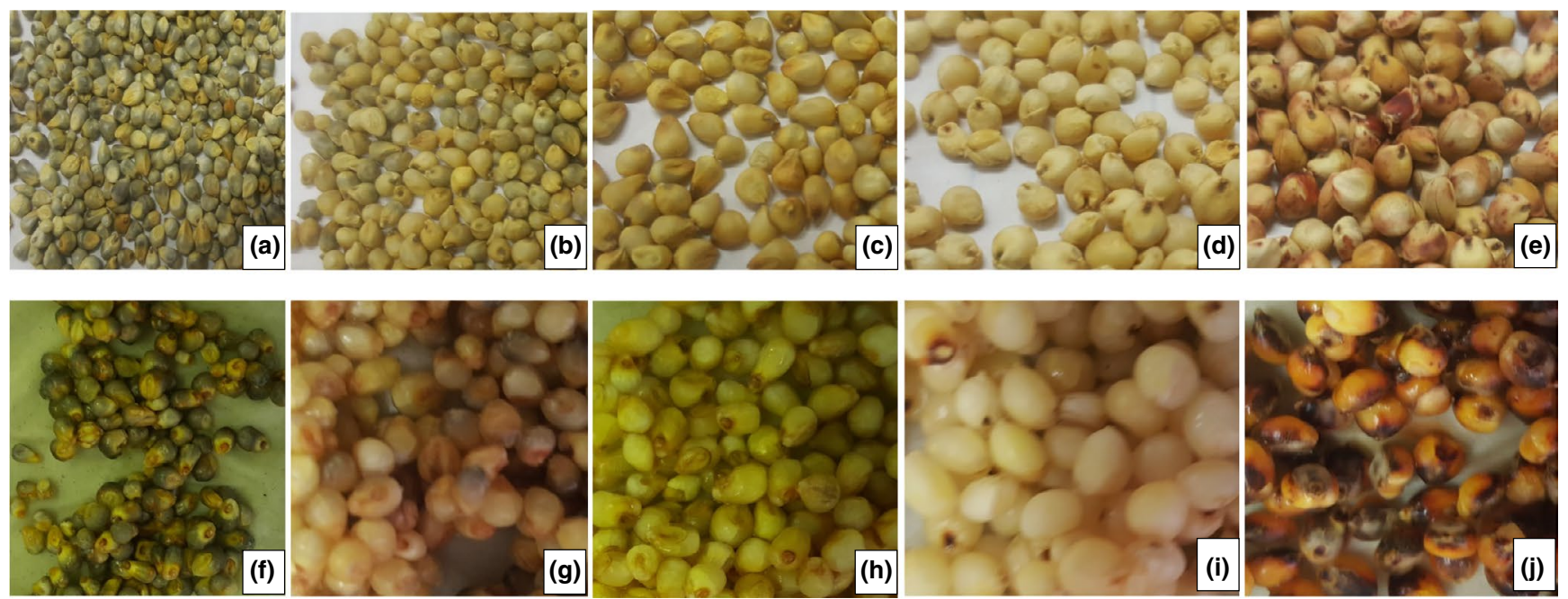

F I G URE 1 Grains before bleach test (left to right) pearl millet (a) Okashana 2, (b) Kantana, (c) Kangara, (d) Macia (white) sorghum, (e) Red sorghum and after bleach test (left to right) pearl millet (f) Okashana 2, (g) Kantana, (h) Kangara, (i) Macia (white) sorghum, (j) Red sorghum [Color figure can be viewed at wileyonlinelibrary.com] 


\subsection{2 | Total phenolic (TPC), flavonoid (FC), condensed tannin (CT) contents, and antioxidant activity}

The total phenolic, flavonoid, condensed tannin contents, and antioxidant activity of pearl millet and sorghum varieties are given in Table 3. The TPC of nongerminated grains was as follows: Kantana $>$ Kangara $=$ Okashana $2=$ Red sorghum $>$ Macia. The TPC of all nongerminated pearl millet and sorghum grains was lower than $70.34 \mathrm{mg} \mathrm{GAE} / \mathrm{g}$ reported by Adebiyi et al., (2017) in nongerminated pearl millet, but was higher than the TPC of $1.387 \pm 0.013$ and $4.128 \pm 0.009 \mathrm{mg} \mathrm{GAE} / \mathrm{g}$ for pearl millet and sorghum, respectively reported by Ragaee et al. (2006). These differences in the TPC can be attributed to the use of different extracting solvents and/or extraction conditions, which can yield different levels of phenolics (Dykes \& Rooney, 2006; Salar, Purewa, \& Bhatti, 2016). Malting significantly $(p \leq 0.05)$ decreased TPC for all the grains. A decrease in TPC was also noted by Sehgal and Kawatra (1998) in pearl millet and in sorghum (Iwuoha \& Aina, 1997) after malting. However, Adebiyi et al., (2017) found an increase in pearl millet TPC after malting. The FC of nongerminated grains differed significantly $(p \leq 0.05)$, except those of Kangara and Red sorghum. Malting significantly $(p \leq 0.05)$ decreased the FC for all the grains, except in Macia, which did not change $(p>0.05)$. Khoddami, Mohammadrezaei, and Roberts (2017) also observed a decrease in FC in sorghum after malting.
The decrease in TPC after malting in pearl millet and sorghum can be attributed to the leaching of phenols during steeping and germination or phenolics entering the endosperm together with imbibed water during steeping and germination, and then, polyphenols may bind with proteins and other macromolecules and become less extractable (Taylor \& Duodu, 2015). TPC decrease could also be due to the activity of enzymes such as polyphenol oxidase (PPO) during germination whereby polyphenols, the substrate of PPO, might be used up.

There was no CT detected in all the pearl millet varieties before and after malting. This is in agreement with McDonought and Rooney (1989) who also detected no CT in pearl millet and with the negative bleach test (Section 3.3.1). However, Lestienne, Besancon, Caporiccio, Lullien-Pellerin, and Treche (2005) found low levels of CT in nongerminated pearl millet. There was also no CT detected in nongerminated Macia, but relatively high CT content was found in nongerminated Red sorghum. Based on this, nongerminated Macia can be regarded as a tannin-free sorghum, whereas the nongerminated Red sorghum can be regarded as tannin sorghum because its CT values were within the range (10.0-68.0 mg $\mathrm{CE} / \mathrm{g} \mathrm{db}$ ), which is regarded as tannin sorghum as suggested by Awika and Rooney (2004). These findings corroborate the Bleach test results (Section 3.3.1). Low levels of CT were observed in Macia and those of Red sorghum significantly $(p \leq 0.05)$ decreased after malting. The CT contents of Red sorghum and Macia malts determined in this study were higher than $20.54 \pm 0.97$ and $0.89 \pm 0.01 \mathrm{mg} \mathrm{CE} / \mathrm{sample}$ in

T A B L E 3 Total phenolic content (TPC), flavonoid content (FC), condensed tannin (CT) content, and antioxidant activity of pearl millet, sorghum nongerminated grains and malted grains varieties

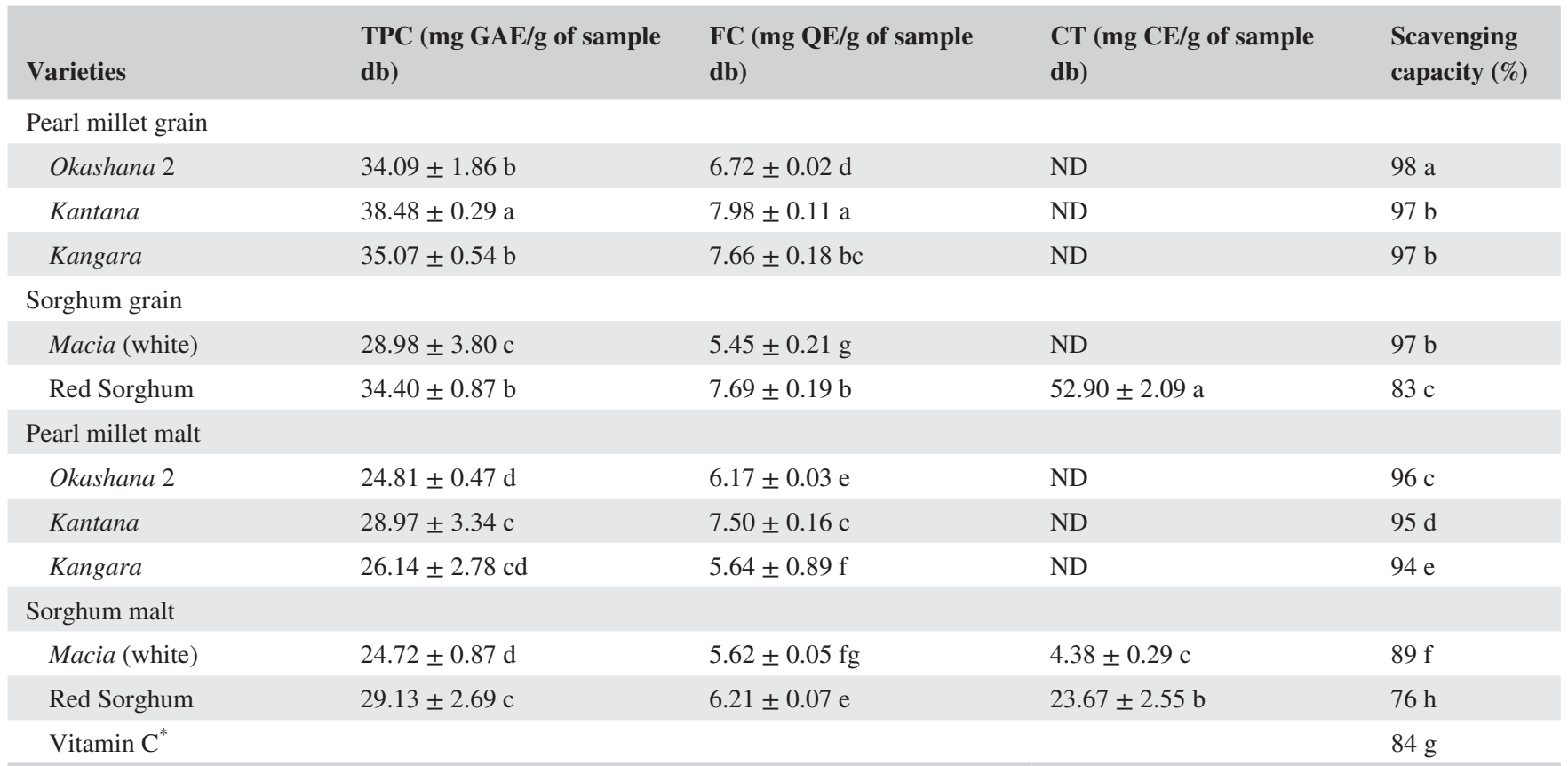

Note: GAE, gallic acid equivalent; QE, quercetin equivalent; $\mathrm{CE}$, catechin equivalent; values are mean \pm standard deviation; values with the same letter in a column are not significantly different $(p>0.05)$; db, dry basis; ND, not detected; *Vitamin C $6.22 \mathrm{mg} / \mathrm{ml} ; n=6$. 
Red and white sorghum, respectively, reported by GaytanMartinez et al. (2017).

The radical scavenging capacities of the nongerminated grains were statistically higher $(p \leq 0.05)$ than those of the malts for all the cereals. Following malting, the radical scavenging capacities significantly decreased $(p \leq 0.05)$ as follows: Okashana $2>$ Kantana $>$ Kangara $>$ Macia $>$ Red sorghum. The capacities for nongerminated and the malts were significantly higher $(p \leq 0.05)$ than that of $6.22 \mathrm{mg} / \mathrm{ml}$ ascorbic acid, except for Red sorghum.

\section{$4 \mid$ CONCLUSIONS}

All the pearl millet varieties and Macia had higher germinative energy values than Red sorghum. Malted pearl millet varieties had the same but significantly higher crude fat contents than the sorghum varieties. Kantana malt had the highest protein content while Okashana 2 and Red sorghum had the lowest. Okashana 2 malt had the highest fiber content than all the other malts. For sorghum varieties, Macia had the highest malting qualities (FAN, reducing sugars, $\alpha$ - and $\beta$-amylases activities), whereas for pearl millet, Kantana had the highest malting qualities. Therefore, Macia and Kantana can be candidates for industrial malting for brewing nonalcoholic and low alcoholic beverages such as Oshikundu and Omalovu (opaque beer). For the delivery of phenolics, Kantana and Red sorghum had higher amounts of phenolic compounds and can potentially be vectors of delivering phenolics into human diets.

\section{ACKNOWLEDGMENTS}

This research was financially supported by the Namibian National Commission on Research, Science and Technology (NCRST) under the Grant number Inc/0814/0018. We are heartily grateful for this support.

\section{CONFLICTS OF INTEREST}

None declared.

\section{ORCID}

Werner Embashu (D) https://orcid. org/0000-0003-4050-162X

Komeine K. M. Nantanga (D) https://orcid. org/0000-0002-1776-3595

\section{REFERENCES}

Abdelrahman, A., Hoseney, R. C., \& Varriano-Marston, E. (1984). The proportions and chemical compositions of hand-dissected anatomical parts of pearl millet. Journal of Cereal Science, 2, 127 133. https://doi.org/10.1016/S0733-5210(84)80025-9

Adebiyi, J. A., Obadina, A. O., Adebo, O. A., \& Kayitesi, E. (2017). Comparison of nutritional quality and sensory acceptability of biscuits obtained from native, fermented, and malted pearl millet (Pennisetum glaucum) flour. Food Chemistry, 232, 210-217. https:// doi.org/10.1016/j.foodchem.2017.04.020

Adebiyi, J. A., Obadina, A. O., Adebo, O. A., \& Kayitesi, E. (2018). Fermented and malted millet products in Africa: Expedition from traditional/ethnic foods to industrial value-added products. Critical Reviews in Food Science and Nutrition, 58, 463-474. https://doi. org/10.1080/10408398.2016.1188056

Ainsworth, E. A., \& Gillespie, K. M. (2007). Estimation of total phenolic content and other oxidation substrates in plant tissues using Folin-Ciocalteu reagent. Nature Protocol, 2, 875-877. https://doi. org/10.1038/nprot.2007.102

AOAC (1995a). Official methods off analysis of AOAC International, 16th ed., method 4.6.01 (962.09). Maryland, USA: AOAC International.

AOAC (1995b). Official methods off analysis of AOAC International, 16th ed., method 4.5.01 (920.39). Maryland, USA: AOAC International.

Awika, J. M. (2017). Sorghum: Its unique nutritional and health-promoting attributes. In J. R. N. Taylor, \& J. Awika (Eds.), Gluten-Free Ancient Grains: Cereal, pseudocereals and legumes: Sustainable, nutritious and health-promoting foods for the 21st century ( $1^{\text {st }}$ ed., pp. 21-54). Cambridge, MA: Woodhead publishing. https://doi. org/10.1016/B978-0-08-100866-9.00003-0

Awika, J. M., \& Rooney, L. W. (2004). Sorghum phytochemicals and their potential impact on human health. Phytochemistry, 65, 11991221. https://doi.org/10.1016/j.phytochem.2004.04.001

Badau, M. H., Nkama, I., \& Jideani, I. A. (2006). Steep-out moisture, malting loss and diastatic power of pearl millet and sorghum as affected by germination time and cultivar. International Journal of Food Properties, 9, 261-272. https://doi.org/10.1080/1094291060 0596233

Bekele, A., Bultosa, G., \& Belete, K. (2012). The effect of germination time on malt quality of six sorghum (sorghum bicolor) varieties grown at Melkassa, Ethiopia. The Institute of Brewing and Distilling, 118, 76-81. https://doi.org/10.1002/jib.19

Blandino, A., Al-Aseeri, M. E., Pandiella, S. S., Cantero, D., \& Webb, C. (2003). Cereal-based fermented foods and beverages. Research International, 36, 527-543. https://doi.org/10.1016/ S0963-9969(03)00009-7

Briggs, D. E. (1998). Malts and Malting (1st ed., pp. 133-228). London: Blackie Academic and Professional.

Chang, C., Yang, M., Wen, H., \& Chern, J. (2002). Estimation of total flavonoids content in propolis by two complementary colorimetric methods. Journal of Food and Drug Analysis, 10, 178-182.

Dias-Martins, A. M., Pessanha, K. L. F., Pecheco, S., Rodrigues, J. A. S., \& Carvalho, C. W. P. (2018). Potential use of pearl millet (Pennisetum glaucum (L.) R. Br.) in Brazil: Food security, processing, health benefits and nutritional products. Food Research International, 109, 175-186. https://doi.org/10.1016/j.foodres.2018.04.023

Dykes, L., \& Rooney, L. W. (2006). Sorghum and millet phenols and antioxidant. Journal of Cereal Science, 44, 236-251. https://doi. org/10.1016/j.jcs.2006.06.007

Ebbah, L., Laryea, D., Barimah, J., \& Djameh, C. (2015). Effect of steeping temperature on the quality of malt and Pito (an indigenous 
Ghanian drink). Journal of the Institute of Brewing, 121, 518-523. https://doi.org/10.1002/jib.265

EBC (1987). Method 8.8.1. Ninhydrin colorimetric method (International method), (4th ed., pp. 141). Zurich: Analytica-EBC, Brauerei-und Getranke-Rundschau.

EBC (1998). Analytica-EBC, EBC-analysis. European Brewery Convention. Nurnberg: Fachverlag Hans Carl.

Embashu, W., Iileka, O., \& Nantanga, K. M. (2019). Namibian opaque beer: A review. Journal of the Institute of Brewing, 125, 4-9. https:// doi.org/10.1002/jib.533

Gaytán-Martínez, M., Cabrera-Ramírez, A. H., Morales-Sánchez, E., Ramírez-Jimènez, A., Cruz- Ramírez, J., ... S. (2017). Effect of nixtamalization process on the content and composition of phenolic compounds and antioxidants activity of two sorghum varieties. Journal of Cereal Science, 77, 1-8. https://doi.org/10.1016/j.jcs.2017.06.014

Hepute, N. R., Embashu, W., Cheikhyoussef, A., \& Nantanga, K. M. (2016). Effect of pre-cooking pearl millet (Pennisetum glaucum) flour on the reduction of dregs in Oshikundu. International Science and Technology Journal of Namibia, 8, 91-97.

INTSORMIL (2008). Sorghum lager and stout beer: A boost to the African economy. INTSORMIL Impact and Bulletins 65. http://digitalcommons.unl.edu/intsormilimpacts/65.

Iwuoha, C. I., \& Aina, J. O. (1997). Effect of steeping condition and germination time on the alpha-amylase activity, phenolic content and malting loss of Nigerian local red and hybrid short Kaura sorghum malts. Food Chemistry, 58, 289-295. https://doi. org/10.1016/0308-8146(95)00215-4

Khoddami, A., Mohammadrezaei, M., \& Roberts, T. H. (2017). Effect of sorghum malting on color, major classes of phenolic and individual Anthocyanins. Molecules, 22, 1713. https://doi.org/10.3390/ molecules22101713

Kutyauripo, J., Parawira, W., Tinofa, S., Kudita, I., \& Ndengu, C. (2009). Investigation of shelf-life extension of sorghum beer (chibuku) by removing the second conversion of malt. International Journal of Food Microbiology, 129, 271-279. https://doi.org/10.1016/j.ijfoo dmicro.2008.12.008

Lestienne, I., Besancon, P., Caporiccio, B., Lullien-Pellerin, V., \& Treche, S. (2005). Iron and zinc in vitro availability in pearl millet flour (Pennisetum glaucum) with varying phytate, tannin and fiber contents. Journal of Agriculture Food Chemistry, 53, 3240-3247. https://doi.org/10.1021/jf0480593

McDonough, C. N., \& Rooney, L. W. (1989). Structural characteristic of Pennisetum americanum using scanning electron and fluorescence microscope. Food Microstructure, 8, 137-149.

Megazyme International (2015). Betamyl-3 and Ceralpha Methods.

Morrall, P., Boyd, H. K., Taylor, J. R. N., \& Der Walt, V. (1986). Effect of germination time, temperature and moisture on malting sorghum. Journal of the Institute of Brewing, 92, 439-445. https://doi. org/10.1002/j.2050-0416.1986.tb04437.x

Nelson, N. (1944). Determination of reducing sugars: Nelson-Somogyi method. Journal of Biological Chemistry, 153, 375-380.

Novellie, L. (1962). Kaffircorn malting and brewing studies. XIII.Variation of diastatic power with variety, season, maturity and age of grain. Journal of the Science of Food and Agriculture, 13, 124 126. https://doi.org/10.1002/jsfa.2740130212

Novellie, L., \& De Schaepdrijver, P. (1986). Modern developments in traditional African beer. Progress in Industrial Microbiology, 23, 73-157.

Nzelibe, H. C., \& Nwasike, C. C. (1995). The brewing potential of "Acha" (Digitaria exilis) malt compared with pearl millet
(Pennisetum typhoides) malts and sorghum (Sorghum bicolor) malts. Journal of the Institute of Brewing, 101, 345-350. https://doi. org/10.1002/j.2050-0416.1995.tb00871.x

Owuama, C. I. (1999). Brewing beer with sorghum. Journal of the Institute of Brewing, 105, 23-34. https://doi.org/10.1002/j.2050-0416.1999. tb00002.x

Pelembe, L. A. M., Dewar, J., \& Taylor, J. R. N. (2002). Effect of malting conditions on pearl millet malt quality. Journal of the Institute of Brewing, 108, 7-12. https://doi.org/10.1002/j.2050-0416.2002. tb00113.x

Ragaee, S., Abdel-Aal, E. M., \& Noaman, M. (2006). Antioxidant activity and nutrient composition of selected cereals for food use. Food Chemistry, 98, 32-34. https://doi.org/10.1016/j.foodc hem.2005.04.039

Ratnavathi, V., \& Chavan, U. D. (2016). Malting and brewing of sorghum. In Sorghum biochemistry: An industrial perspective (1st ed., pp. 63-106). London: Oxford Academic Press.

Salar, R. K., Purewa, S. S., \& Bhatti, M. S. (2016). Optimisation of extraction condition and enhancement of phenolic content and antioxidant activity of pearl millet fermented with Aspergillus awamori MTCC-548. Resources Efficient Technologies, 2, 148-157. https:// doi.org/10.1016/j.reffit.2016.08.002

Sehgal, A. S., \& Kawatra, A. (1998). Reduction of polyphenol and phytic acid content of pearl millet grains by malting and blanching. Plant Foods for Human Nutrition, 53, 93-98. https://doi. org/10.1023/A:1008060604880

Serna-Saldivar, S. O. (2012). Physical and morphological properties of cereal grains. Cereal Grains Laboratory Reference and Procedure Manual (8-9). Boca Raton, FL: CRC Press.

Serna-Saldivar, S. O., \& Espinosa-Ramírez, J. (2019). Grain structure and grain chemical composition. In J. R. N. Taylor, \& K. G. Duodu (Eds.), Sorghum and millet chemistry, technology and nutritional attributes (2st ed., pp. 85-129). Cambridge, MA: Woodhead Publishing. https://doi.org/10.1016/B978-0-12-811527-5.00005-8

Serna-Saldivar, S., \& Rooney, L. W. (1995). Structure and chemistry of sorghum and millets. In D. A. V. Dendy (Ed.), Sorghum and millets: Chemistry and technology, 2nd ed. (pp. 64-124). St Paul, MN: American Association of Cereal Chemists.

Sompong, R., Siebenhandl-Ehna, S., Linseberger-Martina, G., \& Berghofer, E. (2011). Physicochemical and antioxidant properties of red and black rice varieties from Thailand, China and Sri Lanka. Food Chemistry, 142, 132-140. https://doi.org/10.1016/j.foodc hem.2010.05.115

Taylor, J. R. N. (2016a). Millet pearl: overview. In C. Wrigley, H. Corke, K. Seetharaman, \& J. Faubion (Eds.), Encyclopedia of food grains, the world of food grains (2nd ed., pp. 190-198). Oxford: Elsevier.

Taylor, J. R. N. (2016b). Fermentation: Foods and non-alcoholic beverages. In C. Wrigley, H. Corke, K. Seetharaman, \& J. Faubion (Eds.), Encyclopedia of food grains, the world of food grains (2nd ed., pp. 183-192). Oxford: Elsevier.

Taylor, J. R. N. (2017). Millets: Their unique nutritional and health-promoting attributes. In J. R. N. Taylor, \& J. Awika (Eds.), Gluten-Free Ancient Grains: Cereal, pseudocereals and legumes: sustainable, nutritious and health-promoting foods for the 21st century (1st ed., pp. 55-103). Cambridge, MA: Woodhead Publishing. https://doi. org/10.1016/B978-0-08-100866-9.00004-2

Taylor, J. R. N., \& Duodu, K. G. (2015). Effect of processing sorghum and millets on their phenolic phytochemicals and the implication of this to the health-enhancing properties of sorghum and millet food 
and beverages products. Journal of Science Food and Agriculture, 95, 225-237. https://doi.org/10.1002/jsfa.6713

Taylor, J. R. N., \& Duodu, K. (2017). Sorghum and millet: Grainquality characteristics and management of quality requirements. In C. Wrigley, I. Batey, \& D. Miskelly (Eds.), Cereal grains: assessing and managing quality (2nd ed., pp. 317-351). Cambridge, MA: Woodhead Publishing. https://doi.org/10.1016/ B978-0-08-100719-8.00013-9

Taylor, J. R. N., \& Robbins, D. J. (1993). Factors affecting beta-amylase activity in sorghum malts. Journal of the Institute of Brewing, 99, 413-416. https://doi.org/10.1002/j.2050-0416.1993.tb011 81.x

Taylor, J. R. N., \& Taylor, J. (2008). Five simple methods for the determination of sorghum grain end-use quality (with adaptation for those without laboratory facilities. INTSORMIL Scientific
Publication Paper 17. http://digitalcommons.unl.edu/intsormilpubs/17. Accessed 13.06.2017.

Waniska, R. D., Rooney, L. W., \& McDonough, C. M. (2016). Sorghum: utilization. In C. Wrigley, H. Corke, K. Seetharaman, \& J. Faubion (Eds.), Encyclopedia of food grains, the world of food grains (2nd ed., pp. 116-123). Oxford: Elsevier.

How to cite this article: Embashu W, Nantanga KKM. Malts: Quality and phenolic content of pearl millet and sorghum varieties for brewing nonalcoholic beverages and opaque beers. Cereal Chem.

2019;96:765-774. https://doi.org/10.1002/cche.10178 